\title{
The Effect of Competency, Organizational Culture, and Motivation on The Performance of Functional Officers of Surabaya Tanjung Perak Customs Office
}

\author{
Iwan Sutrisna ${ }^{1,}$ Joko Suyono ${ }^{2}$, Arasy Alimudin ${ }^{3}$ \\ ${ }^{1,2}$ Master of Management Student, Universitas Narotama, Department of Management and Business, Surabaya, \\ Indonesia 60117. \\ baloen33@gmail.com
}

\begin{abstract}
Purpose: The objectives of this study is to analyse the effect of competency, organizational culture, and motivation on the performance of functional officers of Surabaya Tanjung Perak Customs Office.

Design/methodology/approach: The data analysis technique used was multiple regression analysis.

Findings: Employee competency is reflected in performance, good competency creates good performance.

Research limitations/implications: The population in this study was 38 functional officers of Surabaya Tanjung Perak Customs Office.

Practical implications: 1) competency affects the performance of functional officers of Surabaya Tanjung Perak Customs Office, 2) organizational culture affects the performance of functional officers of Surabaya Tanjung Perak Customs Office, 3) motivation affects the performance of functional officers of Surabaya Tanjung Perak Customs Office, 4) competency, organizational culture and motivation affect the performance of functional officers of Surabaya Tanjung Perak Customs Office.

Originality/value:

Paper type: This paper can be categorized as case study paper.

Keywords: competency, organizational culture, motivation, performance, functional officers.
\end{abstract}

$\begin{array}{ll}\text { Received } & \text { June } 10^{\text {th }} 2019 \\ \text { Revised } & \text { July } 17^{\text {th }} 2019 \\ \text { Published } & \text { September } 30^{\text {th }} 2019\end{array}$

\section{INTRODUCTION}

Today, the world is entering the era of industrial revolution 4.0. or the fourth world industrial revolution where technology has become the basis of human life. This era has many aspects of life both in economic, political, cultural, artistic, and even to the world of work. The Industrial Revolution 4.0 provided many challenges for all parties must anticipate. If not, there will be many Indonesian workers who are competitive and excluded from the world of work. Rapid technological development has also caused the scope of work to become increasingly vague and workers / employees to be optimalized to improve performance. In every organization, employees are very valuable assets for an organization. The progress or decline of an organization is determined by the employees who work in it. Human resources are the determining factors and the factors that have the most influence on the success of the organization. Human resources are the most important asset of an organization because of its role as the subject of implementing policies and operational activities of an organization. Resources owned by an organization such as capital, methods and machinery cannot provide optimum results if not supported by human resources that have optimum performance. Many efforts are made by companies, agencies, offices or other organizations to improve employee performance. Employee performance is a result achieved by workers in their work according to certain criteria that apply to a particular job. Robbins (2013) expalins that employee performance is a function of the interaction between ability and motivation. Robbins (2013) further states that the setting of performance goals is to set goals that are useful not only for performance evaluation at the end of the period but also for managing the work process during that period. Employee performance is a result achieved by workers in their work according to certain criteria that apply to a particular job. Determination of performance goals is useful for compiling the intended 
target and not only for performance evaluation at the end of the period but also for managing the work process during that period. Mangkunegara (2011) states that performance is the result of work both in quality and quantity achieved by an employee in carrying out his duties in accordance with the responsibilities given to him. Good performance is optimal performance, in the sense that performance is in accordance with organizational standards and supports the achievement of organizational goals, namely the vision and mission of the organization. Improving employee performance will bring progress for agencies or organizations to be sustainable in an unstable competition. Performance is a very important and interesting part because of its proven benefits. Therefore efforts to improve employee performance are the most serious management challenges because the success of an organization to achieve its goals and survival depends on the quality of the performance of human resources in it (Syamsuddinnor, 2014). One of the factors that determine the success of employees in carrying out their duties is competency. According to Edison, Anwar, and Komariyah (2016: 142) competency is the ability of an individual to carry out a job correctly and has an advantage based on matters relating to knowledge, expertise and attitude. Competencies possessed by employees are so important for companies because competencies will be able to influence the level of employee performance. If the competencies possessed by employees are high, performance will increase.

In addition to competency, organizational culture is also very necessary to improve employee performance. Organizational culture is a value system that is obtained and developed by the organization and the basic patterns and philosophies of its founders, which are formed into rules that are used as guidelines in thinking and acting in achieving organizational goals. Culture that grows to be strong is able to spur organizations towards better development. Organizational culture can affect the professionalism of the work of civil servants, because it creates interactions between civil servants and patterns of behavior for civil servants to provide their best ability to take advantage of the opportunities provided by their organizations. Besides good organizational culture that must exist in an organization and the competencies that must be possessed by an employee, an employee can work well if there is work motivation in him. Motivation can influence someone to do something. Motivation is a factor that encourages a person to do a certain activity, therefore motivation is often interpreted as a driving factor for one's behavior (Sutrisno, 2009: 109). Robbins (2013) formulates the notion of motivation as willingness to carry out high efforts, to achieve organizational goals, conditioned by the ability of such efforts, to meet certain individual needs. Koontz (2011) motivation is a reaction that begins with a need, which gives rise to a desire or an effort to achieve a goal, which in turn raises tension, that is a fulfilled wish, causing action that leads to the goal and finally satisfying the desire.

Based on the background described above, the formulation of the problem to be examined in this study are:

1. Does competency partially affect the performance of functional officers of Surabaya Tanjung Perak Customs Office?

2. Does the organizational culture partially affect the performance of functional officers of Surabaya Tanjung Perak Customs Office?

3. Does motivation partially affect the performance of functional officers of Surabaya Tanjung Perak Customs Office?

4. Do competenciy, organizational culture, and motivation simultaneously affect the performance of functional officers of Surabaya Tanjung Perak Customs Office?

\section{Human Resource Management}

According to Nitisemito (2013)human resource management is as an art and science to carry out planning, organizing and supervision so that the effectiveness and efficiency of personnel can be improved in achieving goals. Whereas in the opinion of Gomes (2011), personnel management is the activity of planning, organizing, directing and supervising the procurement, development, compensation, integration and maintenance of employees with the intent to help achieve company, individual and community goals. According to Hasibuan (2010) Management of human resources is needed in an organization, institution or company in the management of workforce or employees.

According to Cherrington (2015), the functions of human resources consist of:

1. Staffng/Employment

This function consists of three important activities, namely planning, withdrawal, and selection of human resources. In fact managers are responsible for anticipating human resource needs. As the company grows, managers become more dependent on the human resources department to gather information about the composition and skills of the current workforce.

2. Performance Evaluation

Performance evaluation of human resources is the responsibility of the human resources department and managers. Managers assume the primary responsibility for evaluating their subordinates and the 
human resources department is responsible for developing effective forms of performance assessment and ensuring that these performance evaluations are carried out by all parts of the company.

3. Compensation

In terms of compensation / reward, a good coordination between the human resources department and managers is needed. Managers are responsible for salary increases, while the human resources department is responsible for developing a good salary structure. The compensation system requires a balance between payments and benefits provided to workers. Payments include salaries, bonuses, incentives, and profit sharing received by employees. Benefits include health insurance, life insurance, leave, and so on. The human resources department is responsible for ensuring that compensation provided is competitive among similar companies, fair, in accordance with applicable law and provides motivation.

4. Training and Development

The human resources department is responsible for helping managers become good coaches and advisors to their subordinates, creating effective training and development programs for new and existing employees, involved in the training and development program, estimate the company's needs for training and development programs, and evaluate the effectiveness of training and development programs. The responsibility of the human resources department in this case also concerns the issue of termination of employment. This responsibility helps restructure the company and provides solutions to conflicts that occur within the company.

5. Employee Relations

In companies that have a labor union, the human resources department plays an active role in negotiating and managing the issue of agreement with the union

6. Safety and Health

The human resources department has the primary responsibility for conducting training on work safety, identifying and improving conditions

7. Personnel Research

In its efforts to improve the effectiveness of the company, the human resources department analyzes the problems of individuals and companies and makes appropriate changes

\section{Competency}

Moeheriono (2010: 3-4) explains that competence is the characteristic that underlies a person with regard to the effectiveness of individual performance in his work. Sedarmayanti (2011: 126) explains that competency is a fundamental characteristic possessed by someone who has a direct effect on excellent performance. Wibowo (2012: 324) explains that competency is a capability to carry out a work based on skills and knowledge and is supported by the work attitude demanded by the job. Based on the above understanding, it can be concluded that competency is the ability in work by integrating knowledge, skills, abilities and personal values based on experience and learning in order to carry out their duties professionally, effectively and efficiently. Moeheriono (2010: 4) explains that in terms of the above competencies, there are several meanings contained therein, namely:

1. The underlying characteristic of competence is a part of personality that is profound and inherent in a person and has predictable behavior in various conditions of work tasks.

2. Causal Relations means that competence can cause or be used to predict a person's performance, meaning that if they have high competence, they will also have high performance.

3. Criteria which is used as a reference that real competence and predicts that someone can work well, must be measurable and specific (standardized).

Moeheriono (2010: 13) suggests that in each individual there are several basic competency characteristics, namely as follows:

1. Character (traits), which is what makes someone have an attitude and behavior or how does the person respond to something in a certain way, such as self-confidence, self-control, fortitude or endurance.

2. Motive, which is something that someone wants or is consistently thought about and desired that results in an action or basis from within concerned to take an action.

3. Self concept, which is the attitude and values that a person has.

4. Knowledge, which is information that someone has in a particular field or area.

5. Skills, the ability to carry out certain tasks both physically and mentally.

Moeheriono (2010: 14) states that one's competency can be influenced by several factors, both from within and from outside, including the following:

1. Innate talent; talents that have existed and are inherent from birth.

2. High work motivation.

3. Attitudes, motives and perspectives. 
4. Knowledge possessed

5. Skills or expertise possessed.

6. The environment of everyday life.

According to Zwell (2012: 56-58) there are several factors that can affect one's competence. These factors include the following:

1. Beliefs and Values

2. Skills

3. Experience

4. Personality Characteristics

5. Motivation

6. Emotional Issues

7. Intellectual Abilities

8. Organizational Culture

Ruky (2016: 107) says that there are various reasons and competency benefits, as follows:

1. Clarifying work standards and direction to be achieved

Skills, knowledge and characteristics of what is needed in the job. And what behaviors influence job satisfaction that ultimately affect performance.

2. Employee selection tools

The use of competencies as an employee selection tool in the organization to select the best prospective employees is expected to have clarity of behavior from employees, effective targets, minimize the cost of recruitment.

3. Maximizing productivity

Achieve employees when developed to cover gaps in skills so that they can maximize their work.

4. Basic development of the remuneration system.

To develop a remuneration system, it will be directed and transparent by associating as many decisions as possible with a set of expected behaviors that are displayed from an employee.

5. Facilitate adaptation to change

To determine what skills are needed to meet changing needs.

6. Completing work behavior with organizational values

To communicate the values and things that should be the focus in the performance of employees

\section{Organizational Culture}

An organizational culture is not itself formed but, all of that through a long process that is concerned with various interactions that occur within the organization. Fahmi (2014: 116) says organizational culture is the result of interactions between:

1. Bias and assumptions of the founders.

2. What was learned by the first members of the organization, who were employed by the founders, from their own experience.

Robbins (2014: 289) suggests that organizational culture is a shared perception held by members of the organization. Organizational culture is a way of thinking and doing something that is inherited, which is shared by all members of the organization and new members learn or at least accept a portion of the culture to be accepted as part of the organization.

\section{Elements of Establishing Organizational Culture}

According to Tika (2014: 16) there are several elements that influence the formation of organizational culture, namely as follows:

1. Business environment.

The survival of an organization is determined by the ability of the organization to respond appropriately to environmental opportunities and challenges. The business environment is the decisive element of what the organization must do to succeed.

2. Values.

Values are the basic beliefs held by an organization. Every organization has core values as a guideline for thinking and acting for all citizens in achieving the organization's goals or mission.

3. Heroes.

Modeling can come from company founders, managers, groups of organizations or individuals who succeed in creating organizational values.

4. Rituals.

Rituals are repeated sequences of activities that express and strengthen the organization's core values, what are the most important goals, which people are important and which ones can be sacrificed 
5. Cultural networks.

Cultural networks are informal communication networks that are basically primary communication channels. Its function is to channel information and provide interpretation of information

Characteristics of Organizational Culture

According to Stephen Robbins (in Fahmi, 2014: 117-118) there are ten main characteristics that differentiate organizational culture, namely:

1. Individual initiatives.

The level of responsibility, freedom and independence that an individual has.

2. Tolerance of risky actions.

The extent to which employees are encouraged to act aggressively, innovatively, and take risks.

3. Directions.

The extent to which the organization clearly creates goals and expectations regarding achievement.

4. Integration.

The extent to which units within organizations are encouraged to work in a coordinated manner.

5. Support from management.

The degree to which managers provide clear communication, assistance, and support for their subordinates.

6. Controls.

The number of direct rules and supervision used to monitor and control employee behavior.

7. Identity.

The degree to which members identify themselves as a whole with their organization is balanced with a particular work group or in the field of professional expertise.

8. Reward system.

The degree to which additional allocations (for example, salary increases, promotions) are based on potential employee criteria as opposed to seniority, favoritism and so on.

9. Tolerance to conflict.

The degree to which employees are encouraged to express conflict and criticism openly.

10. Communication patterns.

The degree to which organizational communication is limited by formal hierarchies of authority.

Function of Organizational Culture

According to Tika (2014: 14) states there are ten main functions of organizational culture, include:

1. Distinguishing limits to the environment, organizations and other groups. This distinguishing limit is due to the existence of a certain identity that is owned by an organization or other group.

2. Adhesive for members in an organization. This is part of the collective commitment of members of the organization. They are proud of being an employee of an organization or company.

3. Promote social system stability. This is illustrated where the work environment is felt positive, supportive, and conflict and change are effectively regulated.

4. Mechanisms in combining and forming the attitudes and behavior of members of the organization. With the widening of the control mechanism, the channeling of structures, the shared meaning given by a strong culture ensures that everyone is directed towards the same direction.

5. Integrator. Organizational culture can be used as an integrator because of the existence of new subcultures. This condition is usually experienced by companies where each unit has a new sub-culture.

6. Establish behavior for members of the organization. Intended so that members can understand how to achieve an organizational goal.

7. Suggestions for resolving key organizational problems. Organizational culture is expected to overcome the problem of adaptation to the external and internal environment.

8. Reference in preparing marketing planning, market segmentation, determining the positioning that will be controlled by the company.

9. Communication equipment. Organizational culture can function as a means of communication between superiors and subordinates or vice versa, and between members of the organization.

10. Inhibiting innovation. Organizational culture can be an obstacle to innovation. This happens when the organizational culture is unable to overcome problems that concern the external and internal environment.

Motivation

Stepen P. Robbins and Mary Coulter (2013) formulating the notion of motivation is "willingness to carry out high efforts, to achieve organizational goals, conditioned by the ability of such efforts, to meet certain individual needs". Koontz (2011) motivation is a reaction that begins with a need, which gives rise to a desire or an effort 
to achieve a goal, which in turn raises tension, that is a fulfilled wish, causing action that leads to the goal and finally satisfying the desire. Handoko (2012) gives a definition of motivation as a force or factor that is contained within humans. George R. Terry (2011) defines motivation is the desire found in an individual who stimulates him to take actions. So the desire of an individual is something that encourages the individual to do something / work. Motivation is an impulse that moves people to behave and in their actions has a specific purpose. According to A. Dale Timpe (2012) motivation must come from oneself, individually, intentionally and in many facets. Motivation is individual in the sense that everyone is motivated by various levels.

\section{Motivation theory}

1. Needs Theory by Abraham H. Maslow

Maslow (2010), has devided human need into the following classes:

1) Physiological or Basic Needs

People must satisfy these needs just to keep alive. They include, for example, hunger, thirst and sleep. In the work environment, the fundamental purpose of a wage or salary is to provide the means of satisfying basic needs

2) Security or Safety Needs

These are concerned with self-protection, with the avoidance of harm. Examples are needs for shelter, warmth and self-defense.

3) Social or Affection Needs

Everyone wishes to give others for recreational purposes are example of these needs. For example, people may join with others partly to satisfy affection needs and partly for greater security.

4) Esteem or Ego Needs

These include the needs to become independent, to receive the esteem of others, to dominate and to acquire possessions.

5) Self-Actualization Needs

This final group comprises the needs to make the fullest use of one's capabilities, to develop oneself and to be creative.

2. Hezberg's Motivation Theory

The American psychologist Frederick Herzberg (2011) has propounded a theory of motivation at work which divides the factors of the work environment into classes: motivators or satisfiers on the one hand; and hygiene factors or maintenance factors on the other.

The Motivating Factors are as follows:

1) Achievement

2) Recognition

3) Responsibility

4) Promotion prospects

5) Work itself - Job Satisfaction

The Hygiene Factors are as follows:

1) Pay / Salaries

2) Relations with others

3) Type of supervisors

4) Company policy

5) Physical working conditions

6) Fringe benefits

\section{ERG Alderfer's Theory}

The theory of motivation related to leadership problems is ERG Theory introduced by Clayton Alderfer. In this theory three groups of needs are introduced, namely Existency, Related needs, and Growth needs that are well known for the ERG acronym. There are three types of needs (Winardi, 2011), namely:

1) Existency is the need to stay alive. This need is almost the same as the physical needs (Maslow's physiological needs) and almost the same as the hygienic factor of Hezberg.

2) Related needs, namely the need to establish relationships with each other in working with others. This need is the same as Maslow's Sociological needs.

3) The need to develop (Growth needs) is a need for a career in his job. If a boss pays attention to the development of his subordinates fairly, he will be rewarded in the form of orders that are carried out properly. 
There are three types of needs that can provide encouragement, namely:

1) The need for power. Such people usually try to find leadership positions, they have a strong will, are very demanding and like to speak in public.

2) Affiliation needs. These people tend to get affection and tend to avoid disappointment if rejected by a group.

3) Needs of achievement. Such people usually have a high desire to always succeed and worry about failure, big responsibilities, like hard and challenging jobs, like working hard and working alone.

\section{Employee performance}

As'ad (2015) states that performance is a successful role achievement obtained by a person or group of people from his actions. According to Steers and Porter (2015) the performance of employees is a combination of three important factors, namely: ability, temperament and interest of a worker; clarity and acceptance of the explanation of the role of a worker; and work motivation level.

\section{Performance Standards}

Accoding to Sofyan (2012), performance standards function as certain goals that must be achieved by employees, must be realistic, measurable and attainable the position. According to Sofyan (2012), performance standards are considered satisfactory if:

1) The statement shows several key areas of employee responsibility

2) Contains how a work activity will be carried out

3) And direct attention to the quantitative mechanism of how the results of its performance will be measured.

Factors Affecting Work Achievement

Gomes (2011) suggests that employee work performance is based on:

1) Quantity of Work, namely the amount of work obtained in a certain period of time.

2) Qualityof Work, namely the quality of work achieved based on the conditions of conformity and readiness.

3) Job Knowledge, the breadth of knowledge about work and skills.

4) Creativeness, namely the authenticity of the ideas raised and actions to solve problems that arise.

5) Cooperative, namely the willingness to work with other people (fellow members of the organization).

6) Dependability, namely awareness and trustworthiness in terms of attendance and completion of tasks.

7) Initiative, which is the spirit of carrying out new tasks and in enlarging its responsibilities.

8) Personal Qualities, which concerns personality, leadership, hospitality, and personal integrity

\section{Performance assessment}

As'ad (2015) states that the first time needed is a measure of success and which parts are considered very important in a job. However, determining the size of success is very difficult because often a job is very complex, making it difficult to determine the exact size of the output. Whereas according to Gomes (2011) Performance assessment is a way of measuring the contributions of individual members of the organization to their organization. So, this performance assessment is needed to determine the level of individual contributions to the organization. Performance appraisal provides an important mechanism for management to use in upgrading previous performance and to motivate future performance improvements. This performance assessment generally covers all aspects of work implementation.

Gomes (2011) states that there are 3 types of performance assessment criteria, namely:

1) Performance assessment based on results

This type of criteria formulates job performance based on achieving organizational goals or final results. Participatory goal setting practice is a very strategic motivational tool because employees are directly involved in decisions regarding predetermined goals. Employees tend to accept these goals as their own goals, and feel more responsible for and during the implementation of goal achievement - that goal.

2) Performance assessment based on behavior

This type of criterion measures the means of achieving goals rather than the end result, where employees can provide precise descriptions of behavior in active participation in work.

3) Judgment-based performance assessment

This is a type of performance assessment that judges based on specific behavior.

The use of performance assessment

Anoraga (2014) explains that using performance appraisal can be specified as follows:

1) Career planning and development

Performance feedback directs career decisions that are career paths that must be studied. 
2) Improving work performance

Implementation feedback allows employees, managers and personnel departments to improve performance improvement activities.

3) Compensation adjustments

Job performance evaluation helps decision makers determine wage increases, bonuses and other forms of compensation.

4) Job placement decisions

Promotion, transfer and demotion are based on past work performance or anticipation.

5) Training and development needs

Poor work performance may require training, so good performance might reflect potential that must be developed.

6) Staffing process deviations

Poor work performance may indicate the strength or weakness of the personnel department staffing procedure.

7) Informational inaccuracies

Poor work performance may indicate errors in job analysis information or human resource plans.

8) Job design errors

Poor work performance may be a sign of error in work design. Performance assessment helps diagnose these errors.

9) Fair employment opportunities

Performance appraisal can accurately ensure that internal implementation decisions are taken without discrimination.

10) External challenges

Sometimes work performance is influenced by factors outside the work environment, such as family, health, financial conditions, or other personal problems.

\section{Hypothesis}

From the description of the background of the problem, the formulation of the problem, the objectives and benefits of the study, the literature review and based on the results of previous studies carried out by previous researchers, a conceptual framework can be made as follows:

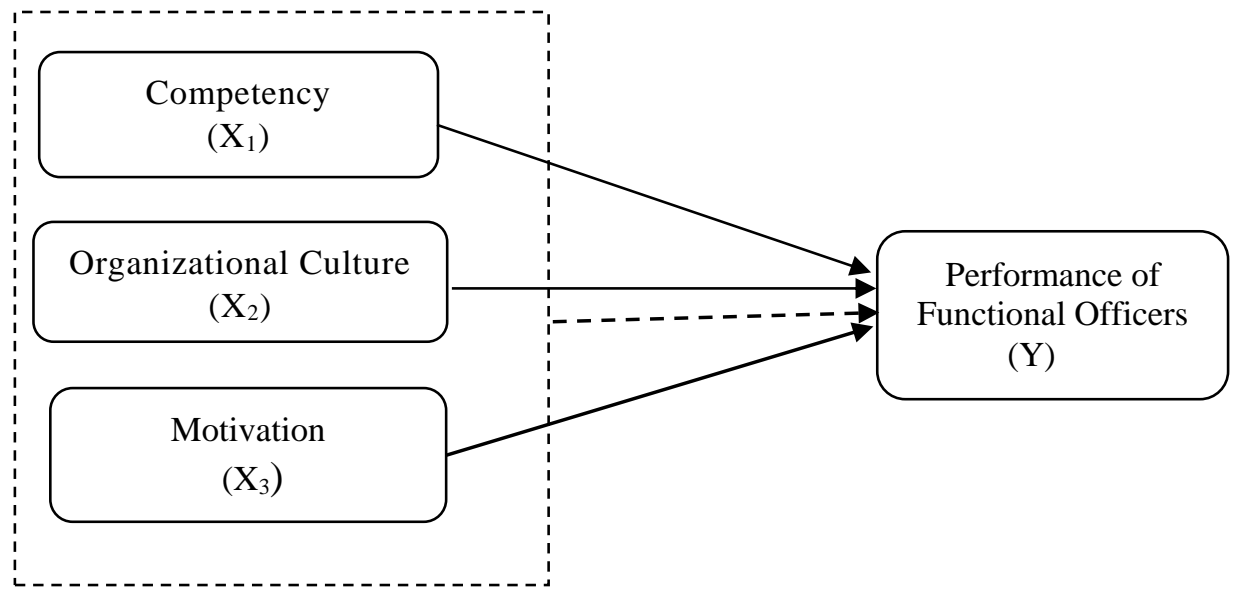

Figure 1: The research model and hypotheses

From the model above, the research hypothesis is arranged as follows:

1. Competency partially affect the performance of functional officers of Surabaya Tanjung Perak Customs Office

2. Organizational culture partially affect the performance of functional officers of Surabaya Tanjung Perak Customs Office

3. Motivation partially affect the performance of functional officers of Surabaya Tanjung Perak Customs Office

4. Competenciy, organizational culture, and motivation simultaneously affect the performance of functional officers of Surabaya Tanjung Perak Customs Office. 


\section{METHODS}

\section{Population and Sample}

Population is the whole of the research objects that can be researched, judged to be able to be chosen to answer the questions posed in the questionnaire in order to find out the results of the research then can be concluded (Sugiyono, 2016: 135). The population in this study was 38 functional officers of Surabaya Tanjung Perak Customs Office. The research sample used a number of respondents selected by total sampling or census, 38 functional officers of Surabaya Tanjung Perak Customs Office were chosen as samples and made respondents in this study.

\section{Data Analysis Techniques}

In order to examine the relationship between independent variables and dependent variables and to analyze research hypothesis proposed, the authors use multiple linear regression analysis with the help of SPSS for Windows.

\section{RESULT AND DISCUSSION}

\section{Multiple Regression Analysis}

Multiple linear test results can be seen in the coefficients table as follows:

Table 1 : Results of Multiple Linear Regression Analysis

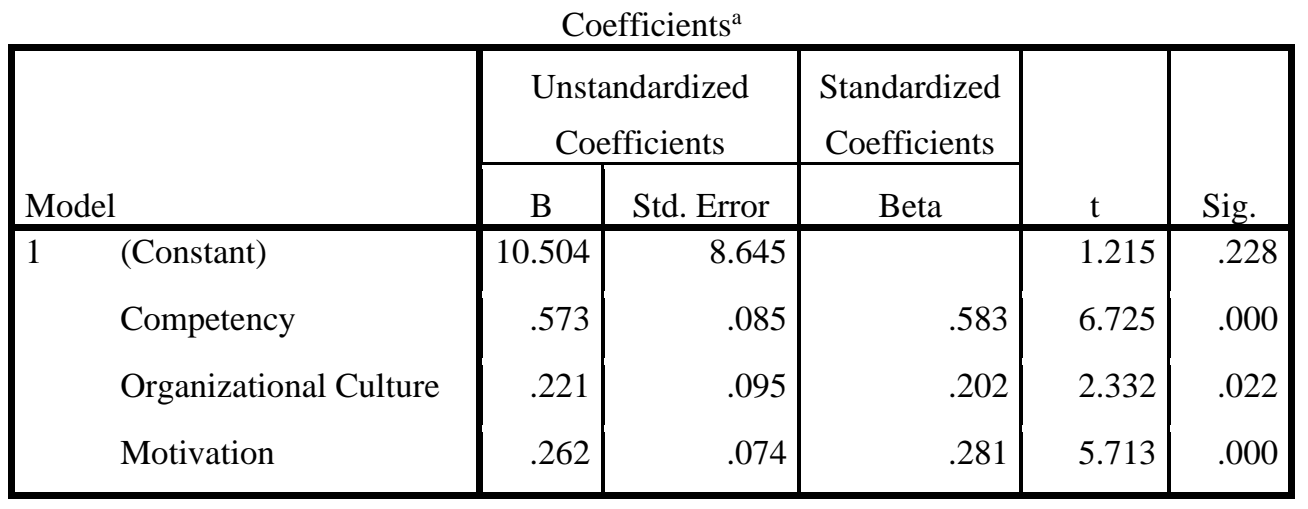

a. Dependent Variable: Y

\section{The effect of competency on the performance of functional officers of Surabaya Tanjung Perak \\ Customs Office}

From the results in Table 1 above it can be seen that the acquisition of the value of $t$ count comperency is 6.725 . Meanwhile, for $t$ table with a significance level of 0.05 , the value of $t$ table is 2.024 . Comparison between the two produces: $t$ count $>t$ table $(6.725>2.024)$. The significance value $t$ for the competency variable is 0.000 and the value is smaller than the probability of $0.05(0.000<0.05)$. So that this test shows that Ha is accepted and Ho is rejected. This means that there is an effect of competency on the performance of functional officers of Surabaya Tanjung Perak Customs Office.

\section{The effect of organizational culture on the performance of functional officers of Surabaya Tanjung Perak Customs Office}

From the results in Table 1 above it can be seen that the acquisition of the value of $t$ count of organizational culture is 2.332. Meanwhile, for $t$ table with a significance level of 0.05 , the value of $t$ table is 2.024 . Comparison between the two produces: $\mathrm{t}$ count $>\mathrm{t}$ table $(2.332>2.024)$. The significance value $\mathrm{t}$ for the organizational culture variable is 0.022 and the value is smaller than the probability of $0.05(0.022<0.05)$. So that this test shows that Ha is accepted and Ho is rejected. This means that there is an effect of organizational culture on the performance of functional officers of Surabaya Tanjung Perak Customs Office.

\section{The effect of motivation on the performance of functional officers of Surabaya Tanjung Perak Customs Office}

From the results in Table 1 above it can be seen that the acquisition of the value of $\mathrm{t}$ count of motication is 5.713. Meanwhile, for $t$ table with a significance level of 0.05 , the value of $t$ table is 2.024 . Comparison between 
the two produces: $\mathrm{t}$ count $>\mathrm{t}$ table $(5.713>2024)$. The significance value $\mathrm{t}$ for the motivation variable is 0.000 and the value is smaller than the probability of $0.05(0.000<0.05)$. So that this test shows that Ha is accepted and Ho is rejected. This means that there is an effect of motivation on the performance of functional officers of Surabaya Tanjung Perak Customs Office.

Table 2 : ANOVA ${ }^{\mathrm{a}}$

\begin{tabular}{|c|c|c|c|c|c|c|}
\hline \multicolumn{2}{|c|}{ Model } & Sum of Squares & df & Mean Square & $\mathrm{F}$ & Sig. \\
\hline \multirow[t]{3}{*}{1} & Regression & 1076.154 & 2 & 538.077 & 17.106 & $.000^{\mathrm{b}}$ \\
\hline & Residual & 2705.127 & 36 & 31.455 & & \\
\hline & Total & 3781.281 & 38 & & & \\
\hline
\end{tabular}

4. The effect of competency, organizational behavior, and motivation on the performance of functional officers of Surabaya Tanjung Perak Customs Office

From table 2 above with the results of data analysis using SPSS calculations obtained F count of 17.106. This shows $\mathrm{F}$ count $(17.106)>\mathrm{F}$ table $(2.85)$ and significance level of $0.000<0.05$. The test results show that the significance value of the simultaneous test (F test) is obtained by a value of 0,000 , thus the significance value obtained is smaller than the probability $\alpha$ specified $(0.000<0.05)$. So Ho is rejected and Ha is accepted. Then conclusions can be drawn conclusion that there is effect of competency, organizational behavior, and motivation on the performance of functional officers of Surabaya Tanjung Perak Customs Office.

\section{CONCLUSION}

Based on the results of the analysis and discussion previously stated, conclusions can be taken as follows:

1. There is an effect of competency on the performance of functional officers of Surabaya Tanjung Perak Customs Office. It can be proven from the comparison between the two yielding: $t$ count $>\mathrm{t}$ table $(6.725>$ $2.024)$. Significance value $t$ for price variable is 0.000 and the value is smaller than the probability of 0.05 $(0.000<0.05)$. So H1 is accepted.

2. There is an effect organizational behavior on the performance of functional officers of Surabaya Tanjung Perak Customs Office. It can be proven from the comparison between the two yielding: $t$ count $>t$ table $(2.332>2.024)$. The significance value of $t$ for the product variable is 0,022 and the value is smaller than the probability of $0.05(0.022<0.05)$. So $\mathrm{H} 2$ is accepted.

3. There is an effect of motivation on the performance of functional officers of Surabaya Tanjung Perak Customs Office. It can be proven from the comparison between the two yielding: $t$ count $>t$ table $((5.713>$ 2024). The significance value of $t$ for the location variable is 0.000 and the value is smaller than the probability of $0.05(0.000<0.05)$. So $\mathrm{H} 3$ is accepted.

4. There is an effect of competency, organizational behavior, and motivation on the performance of functional officers of Surabaya Tanjung Perak Customs Office. It can be proved from the results of the calculation of SPSS obtained F count of 17.106. This shows F count (17.106) > F table (2.85) and significance level of $0,000<0.05$. The test results show that the significance value of the simultaneous test $(F$ test) is obtained by a value of 0,000 , thus the significance value obtained is smaller than the probability $\alpha$ specified $(0,000<$ $0,05)$. So H4 is accepted.

\section{REFERENCES}

Anoraga, Panji. (2014). Manajemen Bisnis. Semarang : PT. Rineka Cipta..

As'ad, Mohammad, (2015). Psikologi Industri, Liberty, Yogyakarta

Cherrington, David J., (2015). The Management of Human Resources, Prentice Hall Inc., New Jersey.

Dale, Timpe, (2013). Seri Manajemen Sumber Daya Manusia Kinerja, Jakarta : PT Elex Media Komputindo

Edison, Emron, Anwar, Yohny dan Komariyah, Imas. (2016). Manajemen Sumber Daya Manusia, Bandung:

Alfabeta.

Fahmi, Irham. (2014). Pengantar Manajemen Keuangan. Bandung: Alfabeta

George, R. Terry, (2011). Principle Of Management, Alih Bahasa Winardi, Bandung : Penerbit Alumni 
Gomes, Faustino, (2011). Manajemen Sumber Daya Manusia, Yogyakarta : Andi Offset.

Handoko, T. Hani, (2012). Manajemen Personalia dan Sumber Daya Manusia, Edisi Kedua, Penerbit BPFE, Yogyakarta

Hasibuan, Malayu. S. P. (2011). Manajemen Sumber Daya Manusia, Jakara : Bumi Aksara.

Herzberg, Frederick. (2011). Herzberg" s Motivation-Hygiene Theory and Job Satisfaction in The Malaysian Retail Sector: The Mediating Effect Of Love Money. Sunway University Malaysia: Teck Hang Tan and Amna Waheed.

Koontz, Harold, (2011). Manajemen, Jakarta: Erlangga.

Mangkunegara, Anwar Prabu, (2011). Manajemen Sumber Daya Manusia Perusahaan. Bandung: PT. Remaja Rosdakarya.

Maslow, Abraham H., (2010), Motivation and Personality, Jakarta : Rajawali

Moeheriono. (2010). Pengukuran Kinerja Berbasis Kompetensi. Surabaya: Ghalia. Indonesia.

Nitisemito, Alex S., (2013). Manajemen Personalia, Edisi Revisi, Jakarta: Penerbit Ghalia Indonesia.

Robbins, P. Stephen, Mary Coulter. (2014). Management. Twelfth Edition. United States: Pearson Education Limited

Robbins, Stephen P. dan Timothy A Judge, (2014). Perilaku Organisasi. Jakarta: Salemba Empat.

Robbins, Stephen. P, (2013). Perilaku Organisasi : Konsep, Kontroversi, Aplikasi, Terjemahan Pujaatmaka Hadyana, Jakarta : PT. Prenhallindo.

Ruky, Achmad S., (2013). Sistem Manajemen Kinerja, Jakarta, PT. Gramedia Pustaka Utama

Sofjan, Assauri, (2012). Manajemen Pemasaran. Jakarta : Rajawali Pers.

Steers, Richard. M dan Porter, (2015), Motivation and Work Behaviour, $\quad$ McGraw-Hill Inc., Singapore

Sutrisno, Edi. (2009). Manajemen Sumber Daya Manusia Edisi pertama. Jakarta: Kencana Prenada Media Group.

Syamsudin Noor. (2014). Penerapan Analisis SWOT Dalam Menentukan Strategi Pemasaran Daihatsu Luxio di Malang (Studi Kasus pada PT. Astra International Tbk. - Daihatsu Malang) Widodo, 2009. Model Pengembangan Evaluasi Strategi.

Tika, Prabundu, (2014). Budaya Organisasi. Jakarta : Salemba Empat.

Winardi, (2012). Motivasi Dan Pemotivasian Dalam Manajemen, Penerbit, Raja Grafindo Persada, Jakarta.

Zwell, Micahel. (2012). Creating a Culture of Competence. New York: John Wiley and Sons, Inc. 